\title{
Review on Phenotypic Characterization and Breeding Practice of Indigenous Chicken Populations in Ethiopia
}

\author{
Andualem Yihun \\ Department of Animal Science, College of Agriculture, Oda Bultum University, Chiro, Ethiopia \\ Email address: \\ andualemyihun95@gmail.com

\section{To cite this article:} \\ Andualem Yihun. Review on Phenotypic Characterization and Breeding Practice of Indigenous Chicken Populations in Ethiopia. \\ International Journal of Ecotoxicology and Ecobiology. Vol. 6, No. 1, 2021, pp. 13-18. doi: 10.11648/j.ijee.20210601.14
}

Received: December 23, 2020; Accepted: February 10, 2021; Published: March 12, 2021

\begin{abstract}
The review was conducted to Phenotypic Characterization and breeding practice of Indigenous Chicken Populations in Ethiopia. Concerned with breeding practice of producers of indigenous chicken were practiced for improved their chicken productivity through cross breeding and pure breeding methods. Indigenous chickens don't have phenotypic standards and their classification is given based on colours and name of place where they are characterized. Still those local chickens are nondescriptive type and show variations in body position, plumage colour, comb type, their adaptation and productivity. Scavenging production systems is the dominant management practices of chicken with small feed supplementation. High incidence of chicken diseases, mainly (NCD) is the major economically important constraints for village chicken production systems followed by feed shortage and predators in the country. Since local chickens have good potential to adapt in different agro-ecology and make available well-appointed source of family protein and income for rural people. Indigenous breeds of chickens are playing an important role in rural economies in most of the developing countries. They play a major role for the rural poor people with respect to their subsidiary income and provide them with nutritious of chicken egg and meat for their own consumption. The present review was made to document the importance of indigenous chicken characterizations and breeding Practices in Ethiopia for rural economy and its improvement with respect to performance.
\end{abstract}

Keywords: Characterization, Indigenous, Review and Selection

\section{Introduction}

Poultry is the largest number of livestock group in the world estimated to be about 23.39 billion, consisting mainly of chickens, ducks and turkeys [1]. Ethiopia is believed to have the largest number of livestock population. According to Central statistical agency [2], there are about 56.53 million chickens in Ethiopia, comprising of 94.31, 3.21 and 2.49\% of indigenous, hybrid and exotic types, respectively. Phenotypic characterization of animal genetic resource (AnGR) generally refers to the process of identifying distinct breed populations and describing their external and production characteristics within a given production environment [3]. The term "breed" is used in phenotypic characterization to identify district animal genetic resource (AnGR) populations as units of phenotypic reference and measurement.

Concerned with breeding practice of respondents for indigenous chicken have practiced for improved their chicken productivity through cross breeding and pure breeding methods. However, the scavenging habit of village chicken population does not allow farmers to directly influence the exact mates of the breeding stock for improvement of their productivity [4].

Ethiopian poultry have a high reproductive performance and are drought resistant. They have also socio-economic importance whereby they provide meat and egg as well as manures feed for fish and serve as the sole or subsidiary livelihood for a large number of small and marginal farmers and landless laborers. Phenotypic variations of traits were relationships, based upon the comparison of morphological characters, are used to estimate variations within breeds and distances between breeds, and to describe them in terms of the frequency of the most typical characteristics. Morphological or phenotypic characterization has been suggested and used to describe classify breeds of farm animal species.

Studies on Characterization of poultry is essential for planning improvement, sustainable utilization and conservation strategies of a breed at local, national, regional 
and global levels [3]. In the absence of baseline characterization information, some breed populations and unique characteristics possessed by them may decline significantly, or be lost, before their value is recognized and measures taken to conserve them [5].

Furthermore, characterization can identify breeds and/or populations which are at risk of extinction or which are highly desired by farmers, and hence is an important input into nation's chicken population development planning [6]. The wide-ranging agro-ecology of Ethiopia has further contributed to the existence of a large diversity of farm animal genetic resources [7]. Characterization of poultry breeds based on their morphological traits variations are the first step towards the use of the available AnGRs. Morphometric measurements have been used to evaluate the characteristics of various breeds of animals, and could provide firsthand information on the suitability of animals for selection. The present review was made to document the importance of indigenous chicken characterizations and breeding Practices in Ethiopia for rural economy and its improvement with respect to performance.

\section{Breeding Objectives of Indigenous Chicken}

(Melaku, Agide., and Salo) [8-10] in South Wollo, in North Shewa and in Hadiya Zone respectively was reported that the breeding Objectives (purpose) of indigenous Chicken production was source of cash income more important than egg production, meat production for home consumption and cultural/religious practice.

According to Melaku [8], reported the purpose of keeping poultry was, for Source of income, for Egg production, Meat production for home consumption and for Cultural/Religious practice; 0.49 Index value, 0.30 Index value, 0.17 Index value and 0.14 Index value, in South Wollo respectively And (Agide, [9]) also reported that the purpose of keeping poultry in North Shewa was mainly, 0.34 Index value for source of Income, 0.297 Index value Meat production for home consumption, 0.19 Index value for Egg production and 0.164 Index value for Cultural/Religious practice and also the Purpose of egg production in South Wollo were 0.363 Index value, 0.35 Index value and 0.287 Index value for cash income, For hatching and For consumption respectively were reported [9].

Salo [10] the main objectives of keeping poultry were as sources of income $(55.6 \%)$ and followed by home consumption (13.3\%) and both consumption and income $(26.7 \%)$ which is in one-way or other improve the nutrition status of the family. The rest rise chicken for religious sacrifice $(2.2 \%)$ and other purpose $(2.2 \%)$.

To increase and sustain the productivity of poultry so as to respond to the growing domestic and foreign demands for live poultry and its products, improvement programs are necessary and should be crafted, especially for countries like Ethiopia where extensive system of husbandry is the commonest type.

But the Purpose of rural producers of indigenous chicken were high for egg production reported by Mearg [11] in the Central Tigray, this was 0.334 Index value for egg production, 0.157 Index value for Cultural/Religious practice, 0.115 Index value Meat production for home consumption and 0.101 Index value Source of income respectively, was reviewed in Table 1 below.

Table 1. Breeding Objectives (Purpose) of Indigenous Chicken Production in Ethiopia.

\begin{tabular}{|c|c|c|c|c|c|}
\hline Breeding Objectives of chicken & Source of income & Egg production & Cultural/Religious & Meat production for home consumption & Source \\
\hline \multirow{5}{*}{ Production } & 0.34 Index & 0.19 Index & 0.164 Index & 0.297 Index & [8] \\
\hline & $55.6 \%$ & - inco, con $26.7 \%)$ & $2.2 \%)$ & $13.3 \%$ & [10] \\
\hline & 0.49 Index & 0.30 Index & 0.14 Index & 0.17 Index & [9] \\
\hline & 0.101 Index & 0.334 Index & 0.157 Index & 0.115 Index & [11] \\
\hline & 0.284 Index & 0.234 Index & - & 0.358 Index & [12] \\
\hline \multirow{4}{*}{ Purpose of egg production } & 35 & 30.0 & 15.56 & $19.4 \%$ & [13] \\
\hline & For hatching & For cash income & & For consumption & \\
\hline & 0.35 Index & 0.363 Index & & 0.287 Index & [9] \\
\hline & $36.7 \%$ & $39.4 \%$ & & $23.9 \%$ & [13] \\
\hline
\end{tabular}

\section{Breeding Practice of Indigenous Chicken}

The Clear definition of breeding objectives might be difficult under subsistence level of managements with a wide range of production objectives and marketing strategies.

Poultry's are distributed in all agro-ecological zones of the Ethiopia while the majority of the poultry population is found in large flocks in lowlands in pastoral and agro-pastoral production systems, in arid and semi-arid agro-ecological zones, where poultry are kept by nearly all pastoralists, often in mixed flocks with cattle, goats, sheep, freely grazing or browsing in the rangelands.

In Ethiopia, depending on the environmental and social conditions different management systems are prevailing in poultry production. The majority of systems are operated by smallholder farmers and described under low input production system which is characterized by land scarcity, severe resources degradation and recurrent drought [13].

To improve the productivity of local chicken population breeds, by using cross breeding of exotic chicken breeds with the local chicken breeds and Chickens that were not retained for breeding purposes were culled through sale and home Consumption these were conducted by researchers. Ermias [14] reported that $65.6 \%$ carried out cross breeding, where 
$59.4 \%$ carried out uncontrolled breeding and $86.1 \%$ of the respondents did not know the effect of uncontrolled cross breeding on local chicken breeds. In other report rural areas of North Wollo of Ethiopia, mostly farmers practiced cross breeding to improve the productivity of chicken reported by [15]. According to Ermias [14] respondents replied that uncontrolled breeding will reduce disease resistance of crossbreds, may increase the chance of new disease type transmissions, crossbreds may not as hardy as local birds to the environment, brooding nature of local hens was decrease hatchability of eggs and reduce good flavor quality of local chicken meat and eggs were reported [14].

Concerned with different studies in different part of
Ethiopia revealed that village chicken breeding was reported by Addis [6]; $89.21 \%$ was uncontrolled and $10.78 \%$ was Controlled in Gonder and Markos [4] also 96.4\% was uncontrolled and $3.6 \%$ was only Controlled respectively were reported. The scavenging habit of village chickens does not allow farmers to directly (control) influence the exact mates of the breeding stock. However, Mearg [11] 66.50\% was Controlled and $33.50 \%$ was uncontrolled in centeral Tigray.

Depend on Mearg [11] reported that breeding practice $80.1 \%$ of respondents had practiced breeding in improved their chicken productivity through cross breeding $(60.3 \%)$ and pure breeding $(39.7 \%)$ methods. Some results were review in table 2 below.

Table 2. Breeding (crossing) System of indigenous chicken in Ethiopia.

\begin{tabular}{|c|c|c|c|c|c|}
\hline \multicolumn{6}{|l|}{ Agro-ecology } \\
\hline Mating system & Lowland & Midland & Highland & Over all mean & Source \\
\hline Controlled & $7.5 \%$ & $1.5 \%$ & - & $3.6 \%$ & \multirow{2}{*}[4]{} \\
\hline Uncontrolled & $92.5 \%$ & $98.5 \%$ & $100 \%$ & $96.4 \%$ & \\
\hline Controlled & - & $56.8 \%$ & $79 \%$ & 66.50 & \multirow{2}{*}{ [11] } \\
\hline Uncontrolled & - & $43.2 \%$ & $20.9 \%$ & 33.50 & \\
\hline Controlled & $17.92 \%$ & $12 \%$ & $2 \%$ & $10.78 \%$ & \multirow{2}{*}{ [9] } \\
\hline Uncontrolled & $82.07 \%$ & $88 \%$ & $98 \%$ & $89.21 \%$ & \\
\hline Uncontrolled & 83.33 & 81.66 & 88.3 & 84.4 & [13] \\
\hline
\end{tabular}

\section{Breeding and Selection Practices of Indigenous Chicken}

The removing (culling) of indigenous chicken and selection criteria for breeding cock and hens were reviewed in Table 3. According to Mearg [11] were reported that average indigenous chickens $78.9 \%$ of producers cull chickens with an age of 4.31 and 4.51 month to male and female birds. Melaku [8] also reported that All producers in South Wollo were practiced selection to pick breeding and replacement males and females to improve the genetic parts and to obtain well performed chickens based on eight trait categories such as plumage color, live weight, comb type, conformation, breeding ability of chickens, disease resistance ability, plumage colour and comb type and number of egg laid per hen.

According to Solommon [16] discovered that $63.1 \%$ of the respondents were trying to improve the genetic potential of local chicken through selection based on egg production history $(59.4 \%)$, body weight $(44.3 \%)$ and feather colour (25.5\%). Selection was made on males $(55.2 \%)$, females $(20 \%)$ and both male and females $(24.8 \%)$. In addition to selection, $37.1 \%$ households were upgrading the genetic potential of the local chicken through crossbreeding with exotic breeds.

In breeding programs for most species, animals in cock and hen selection pathways are selected very intensely with a higher accuracy than in the other selection pathways. Poultry owners were selected highly interested in body size (conformation), fast growth rate, egg yield, and drought tolerance (adaptability) and disease tolerance and reproduction rate [13].

Breeding objectives were linked to be genetic improvement of different character as practiced with selection criteria including economically important traits related to plumage color, body weight, adaptation, reproductive performance and egg number [9].

Table 3. Breeding and Selection Practices of indigenous chickens in Ethiopia.

\begin{tabular}{|c|c|c|c|c|c|c|c|}
\hline \multirow{2}{*}{ Selection criteria } & \multicolumn{6}{|l|}{ Selection Practices } & \multirow{2}{*}{ Source } \\
\hline & Egg number \& size & Comb type & Growth rate & Disease Tolerance & Plumage colour & Hatchability & \\
\hline Cock & 0.093 & 0.146 & 0.33 & 0.115 & 0.163 & 0.08 & \multirow{2}{*}[12]{} \\
\hline Hen & 0.185 & 0.022 & 0.33 & 0.114 & 0.132 & 0.206 & \\
\hline Cock & - & 0.2 & 0.19 & 0.06 & 0.27 & - & \multirow{2}{*}{ [8] } \\
\hline Hen & 0.25 & - & 0.20 & 0.06 & 0.22 & 0.17 & \\
\hline Cock & - & 0.1 & 0.38 & 0.31 & 0.19 & - & \multirow{2}{*}{ [17] } \\
\hline Hen & - & 0.1 & 0.373 & 0.317 & 0.19 & - & \\
\hline Cock & 0.053 & - & 0.041 & 0.044 & 0.045 & 0.032 & \multirow{3}{*}[11]{} \\
\hline Hen & 0.031 & - & 0.033 & 0.054 & 0.064 & 0.042 & \\
\hline Lowland & $34.91 \%$ & - & $20.75 \%$ & $3.77 \%$ & $44.34 \%$ & $6.6 \%$ & \\
\hline Midland & $33 \%$ & - & $19 \%$ & $2 \%$ & $31 \%$ & $4 \%$ & \multirow[t]{2}{*}[15]{} \\
\hline Highland & $46 \%$ & - & $14 \%$ & - & $37 \%$ & $3 \%$ & \\
\hline
\end{tabular}




\section{Variation in Qualitative Traits}

The classical description of breeds using the phenotype is based upon morphological characters such as plumage color, shank length, neck length, body measurements and other specific visible traits. This category of traits covers the external physical form, shape, color and appearance of animals which are recorded as discrete or categorical [3]. According to Melaku [8] The overall percentage of white, red and brown eye color of chicken were $34.33 \%, 26.33 \%$, and $15.17 \%$, respectively whereas $14.67 \%$ and $9.0 \%$ of hen populations had pearl and blue eye colours were reported. Eskinder [18] also selected that $81.84 \%$ chicken population in Horro and $72.48 \%$ of chicken population in Jarso had orange eye colour whereas 9.01 and $23.31 \%$ of chicken population had red eye colour in Horro and Jarso, respectively.

Mearg, [11] were reported that large variations in morphological appearances of Local chicken were mostly normally feathered (hens $97.8 \%$, cocks $96 \%$ ) with a few showing necked neck $(0.6 \%)$ and feathered shank and feet $(2 \%)$. The highest proportion of eye color was orange (hens $96.1 \%$, cocks $98 \%$ ) followed by brown (hens $2.2 \%$, cocks $2 \%$ ) yellow, blue and red. In addition, the predominant earlobe color was white and red $(35.7 \%)$, black $(33.7 \%)$ red $(28.9 \%)$ white and black orange and white in lower proportion. The commonest shank color also white $(47.1 \%)$, yellow $(26.1 \%)$, black $(9.1 \%)$, brown $(5.6 \%)$, green $(5.2 \%)$, gray blue $(3.2 \%)$, red $(1.7 \%)$, and orange $(1.5 \%)$, respectively reported by [11].

According to Melaku [8] were divers plumage colour white $(19.5 \%)$, black $(11.33 \%)$, and black with white stripes $(10.17 \%)$ and dira (red wheaten) were the most predominant colour. The white earlobe was the commonest color in Borena (46.1\%) and Legambo (49.5\%) but red and white in Wogdi (38.5\%). (Addis [6]) reported that chicken having red $(26.9 \%)$ white $(15.60 \%)$, gebsma (greyish) (14.2\%) and black $(11.5 \%)$ plumage colour were predominately found in North Gonder. Eskinder [18] also reported that red and white earlobes shows $41.4 \%$ and $49.5 \%$ in Horro and Jarso ecotypes, respectively. The common comb types of indigenous chicken are rose, pea, walnut/strawberry, single and $\mathrm{V}$-shape and the large variations in plumage colours may be the result of their geographical isolation as well as periods of natural and artificial selections.

Alem [19] also reported that red color was the most dominant and accounted for $52.3 \%$ followed by greyish (segemo), which was accounted for $20.9 \%$ and multi-colour (Checheq) that accounted for $14.1 \%$. Some of the multicoloured chickens were of brown color with white spots, red with white spots, deep red with black strips, and white with black spots. This multi colour plumage was observed more in male chickens (cocks and cockerels) than in female chickens (hens and pullets) in central zone of Tigray [19].

Eskindir [18] reported that different in Chickens predominantly have brown mottled plumage color, $20.27 \%$ and $21.10 \%$ in Horro and Jarso districts respectively and also the same author showed that a complete body red plumage is typical of $17.12 \%$ and $15.60 \%$ of chickens from Horro and Jarso districts respectively. Other side of the country reported by Haile Michael [20] Plumage colors were $24.17 \%$ red followed by $13.33 \%$ white and $13.06 \%$ black in local population of Southern Zone of Tigray. In addition, reported Plumage pattern of neck, body, and tail of Chicken was dominantly $55 \%, 60.7 \%$ and $58 \%$ (mottled) respectively. The eye and shank colors were dominant $40.7 \%$ (golden brown) and $61.5 \%$ (blue) reported by [20].

Abebe [21] also reported that color patterns and plumage colors were neck, body and tail were $55.7 \%, 60.7 \%$, and $58 \%$ of (mottled) respectively, followed by $16.5 \%$ (barred) and $17 \%$ of (plain), Ear lobe color were dominated with $45.2 \%$ white and red, $39.2 \%$ red, and $13.8 \%$ non-pigmented while Eye color was $42.2 \%$ golden, $31.7 \%$ sunburst, and $11.9 \%$ flamed colored and Shank color also $61.5 \%$ blue and $23.5 \%$ white were reported by [21] in Guji Zone of Oromia region.

\section{Variation in Quantitative Traits}

This category of traits covers the size and dimensions of animals' bodies or body parts, which are more directly, correlated to production traits than qualitative traits and have continuous expression because of numerous genes that determine their expression [3]. Productivity figures of indigenous chicken in some parameters were reviewed in different part of the country.

(Addis; Agide, melaku and Mearg; [6, 9, 8, 11] were reported that 1.63 and $1.37,1.18$ and $1.10,1.35$ and 1.19 and 1.54 and1.31) male and female average body weight respectively, in Gonder, in North Shewa, in South Wollo, and in the Central Tigray of indigenous chicken populations respectively. However, Abebe [21] in Guji zone of Oromia Regional state Ethiopia, that was (2.1) male and (1.5) female of average body weight reported highest body weight; some quantitative traits were reviewed also in table 4 below.

Eskindir [18] reported that, the average body weight of local adult hens in Horro and Jarso were $1.29 \mathrm{~kg}$ and $1.12 \mathrm{~kg}$, respectively. In addition, Haile Michael [20] also reported that the mean body weight of indigenous male and female chickens was $1271 \pm 12.6 \mathrm{~g}$ and $1034 \pm 8.05 \mathrm{~g}$, respectively in Tigray region.

Characterization is corner stone for efficient and effective management of poultry breeds for conservation, especially for those, which are not adequately characterized and are in danger of becoming threatened but are better performing in stress full environment [13].

Therefore, various qualitative and quantitative traits of indigenous chickens were identified in the different part of the country. But in rural backyard poultry production system, the qualitative and quantitative traits of indigenous chickens across the different agro-ecological zones have not yet addressed [18]; The possible reason of this variation is due to influence of genetic and environmental factors that exposed 
chickens in Ethiopian in different regions. Some quantitative traits were reviewed in table 4 below.

Table 4. Characterization of Body weight $(\mathrm{kg})$ and linear body measurements $(\mathrm{Cm})$ of indigenous chickens in Ethiopia.

\begin{tabular}{|c|c|c|c|c|c|c|}
\hline \multirow[b]{2}{*}{ Sex of chicken } & \multicolumn{5}{|c|}{ Quantitative traits } & \multirow[b]{2}{*}{ Source } \\
\hline & Bwt (kg) & Ws & BI & SI & Ce & \\
\hline Cock & 1.63 & 38.09 & 36.77 & 8.08 & - & \multirow[b]{2}{*}{ [6] } \\
\hline Hen & 1.37 & 36.52 & 35.29 & 7.64 & - & \\
\hline Cock & 1.35 & 39.93 & 37.27 & 10.4 & 25.72 & \multirow{2}{*}{ [8] } \\
\hline Hen & 1.19 & 37.63 & 35.77 & 9.68 & 24.98 & \\
\hline Cock & 1.18 & 38.9 & 37.82 & 6.04 & 24.98 & \multirow{2}{*}{ [9] } \\
\hline Hen & 1.10 & 38.0 & 36.57 & 5.92 & 25.06 & \\
\hline Cock & 1.39 & 36.7 & 32.1 & 9.7 & 30 & \multirow{2}{*}[12]{} \\
\hline Hen & 1.36 & 33.3 & 29.4 & 8.8 & 28.5 & \\
\hline Cock & 1.54 & 36.27 & 27.26 & 11.01 & 29.67 & \multirow{2}{*}{ [11] } \\
\hline Hen & 1.31 & 32.17 & 26.14 & 9.43 & 28.69 & \\
\hline Cock & 2.1 & 47.4 & 43.4 & 9.7 & 31.30 & \multirow{2}{*}{ [21] } \\
\hline Hen & 1.5 & 40.7 & 38.9 & 8 & 27.40 & \\
\hline Cock & 1.78 & 37.89 & 36.24 & 27.53 & 9.95 & \multirow{2}{*}{ [13] } \\
\hline Hen & 1.51 & 36.85 & 35.26 & 26.59 & 9.10 & \\
\hline
\end{tabular}

Bwt (Body weight), Ws (Wing span), Bl (Body length), Sl (Shank length) and Cc (Chest circumference)

\section{Conclusion}

In ethiopia, the agricultural sector is a corner stone of the economic and social life of the people since they are used for generation of extra cash incomes, provision of animal protein and religious/cultural/ considerations. Understanding the situation of poultry rearing was crucial for improvement of poultry products and to design poultry breeding strategy. Indigenous breeds of chickens are playing an important role in rural economies in most of the developing (underdeveloped) countries. They play a major role for the rural poor and marginalized section of the people with respect to their subsidiary income and provide them with nutritious of chicken egg and meat for their own consumption of their family. To increase and sustain the productivity of poultry so as to respond to the growing domestic and foreign demands for live poultry and its products, improvement programs are necessary and should be crafted, especially for countries like Ethiopia where extensive system of husbandry is the commonest type. Indigenous chickens do not have phenotypic standards and their classification was given based on colours and name of place where they were characterized. Still those local chickens are non-descriptive type and show variations in body position, plumage colour, comb type, their adaptation and productivity.

\section{References}

[1] FAOSTAT Database, 2012. Retrieved October 10, 2014, from http://faostat.fao.org/faostat/, FAO, Rome.

[2] CSA (central statistical agency).2016/17 [2009 E. C.] livestock and livestock characteristics (private peasant holdings); agricultural sample survey volume 2, federal democratic republic of Ethiopia, Addis Ababa, Ethiopia.

[3] FAO, (Food and Agriculture Organization of the United Nations). 2012. Phenotypic characterization of animal genetic resources. FAO Animal Production and Health Guidelines No. 11. Rome.
[Accessedon 25.05.2014]. available at http://www.fao.org/docreep/015/i2686e/i2686e00.pdf.FAO, Rome.

[4] Markos, S., Berhanu, B. and Tadelle, D., 2016. On Farm Performance Evaluation of Three Local Chicken Ecotypes in Western Zone of Tigray, Northern Ethiopia. Performance improvement, 5 (7).

[5] FAO (Food and Agricultural Organization of the United Nations), 2007. Global Plan of Action for Animal Genetic Resources and the Interlake Declaration. Rome (available at http://www.fao.org/docrep/010/a1404e/a1404e00.htm) (Accessed 07/01/2018).

[6] Addisu, G. and Aschalew, T., 2014. A Phenotypic and Genetic Characterized Indigenous Chicken Ecotypes in Ethiopia. International Journal of Genetics, 4 (1), 04-10.

[7] IBC (Institute of Biodiversity Conservation), 2004. The State of Ethiopia's Farm animal Genetic Resources: Country Report. A Contribution to the First Report on the State of the World's Animal Genetic Resources. IBC, May 2004. Addis Ababa, Ethiopia.

[8] Melaku, T. A. and Negassi, A., 2016. On farm Phenotypic Characterization of Indigenous Chicken Population and Their Production System at Wogdi, Borena and LegamboDistricts in South Wollo Ethiopia (Doctoral dissertation, Harmaya University).

[9] Agide Yisma. 2015. On- Farm Phenotypic Characterization of Indigenous Chicken and chicken Production Practices in North Shewa Zone, Amhara, Ethiopia Thesis Submitted to the School of Animal and Range Sciences, Haramaya University, Haramaya, Ethiopia.

[10] Salo S*, Tadesse G and Hilemeskel D, 2016. Village Chicken Production System and Constraints in Lemo District, Hadiya Zone, Ethiopia Poultry, Fisheries \& Wildlife Sciences.

[11] Mearg, F. E. A. R. G., 2016. Phenotypic characterization of local chicken ecotypes in the Central Zone of Tigray in northern Ethiopia (M. ScThesis, Jimma University).

[12] Taju, S.,(2017) Phenotypic Characterization and Assessment of Management Practices of Indigenous Chicken in Jimma Zone, Master's Thesis, 2017, P-170 Jimma university, Jimma, Ethiopia. 
[13] Andualem Y. et al. 2020. Characterization of Marketing and Management System of Indigenous Chicken Ecotypes in Awi Zone, Ethiopia, Ecology and Evolutionary Biology. Vol. 5, No. 4, 2020, pp. 131-139. doi: 10.11648/j.eeb.20200504.13.

[14] Ermias T Tsadik, Berhan Tamir and Zemelak Sahile12015. Husbandry practices of village poultry technology package and the nutritional quality of majorly used poultry feeds in the Central Oromia Region, Ethiopia. Livestock Research for Rural Development 27 (4) 2015.

[15] Addisu H., 2013. Phenotypic Characterization of Indigenous Chicken Ecotypes in NorthWolloAmhara Regional State. MSc Thesis, Wollo University, Wollo, Ethiopia.

[16] Solomon Zewdu, Binyam Kassa, Bilatu Agza and Ferede Alemu. 2013. Village chicken production systems in Metekel zone, Northwest Ethiopia. Wudpecker Journal of Agricultural Research, Vol. 2 (9), pp. 256-262.

[17] Gebremariam B, Mazengia H, Gebremariam T (2017) Indigenous Chicken Production System and Breeding Practice in Southern Tigray, North Ethiopia. Poult Fish Wildl Sci 5: 179. doi: 10.4172/2375-446X.1000179.
[18] Eskindir, K., Tadelle D., and Banerjee, A. K. 2013. Phenotypic Characterization of Indigenous Chicken Population in Ethiopia. International Journal. Ethiopia. African Journal of Agricultural Research, 8 (11): 1014-1021.

[19] Alem, A. T., Yayneshet, G. T. and Aklilu, A. H., 2014. Socioeconomic characteristics of poultry production in lowland and midland agro-ecological zones of central Tigray, Ethiopia. International Journal of Livestock Production, 5 (4); 71-80.

[20] Hailemichael Nigussie Kefelegn Kebede Negassi Ameha 1015. Phenotypic and Morphological Characterization of Indigenous Chicken Populations in Southern Zone of Tigray, Ethiopia Journal of Biology, Agriculture and Healthcare, ISSN 2224-3208 (Paper) ISSN 2225-093X (Online) Vol. 5, No. 21, 2015. www.iiste.org.

[21] Abebe, H., Manaye, M., Abrahm, and, Fassil, 2017. On-Farm Phenotypic Characterization of Indigenous Chicken Populations in Guji Zoneof Oromia National Reginal State, Ethiopia. International Journal of Development Research Vol. 07, Issue, 11, Pp. 16652-16661. 